\title{
基于关联规则算法的英语教学行为的影响研究 Research on the influence of English teaching behavior based on association rules algorithm
}

\author{
肖菲 \\ 中国民航飞行学院 空中乘务学院 \\ Xiao Fei \\ Cabin Attendant College, Civil Aviation Flight University of China \\ DOI:10.32629/mef.v2i2.55
}

[摘要] 随着经济全球化的发展和中国企业的不断进步,中国企业在全球经济浪潮中发挥着重要作用,其参与程度也越来越 深入。但这在一定程度上也带来了沟通上的一些麻烦。对英语人才的需求越来越大, 这就要求我们教育机构根据市场情况, 尤 其是在技术人才短缺的情况下, 及时调整教学内容。本文通过研究关联规则算法对英语教学行为的影响, 探讨了如何更有效地 开展英语应用教学。

[Abstract] With the development of economic globalization, Chinese enterprises play an important role in the wave of global economy and their participation is deeper and deeper. It also brings a lot of troubles in communication. The demand for English talents is increasing, which requires our educational institutions to adjust the content of the teaching in a timely manner according to the market situation, especially in the case of a shortage of skilled personnel. Through the study of the influence of the English teaching behavior based on the association rules algorithm, this paper discussed how to carry out the teaching of English application more efficiently.

[关键词] 关联规则; 英语教学行为; 影响

[Key words] association rules; English teaching behavior; influence

\section{INTRODUCTION}

Since the end of the 1970s, the management mode of related enterprises is becoming more perfect due to the reform of the domestic market economic system. The entry of WTO speeds up the construction of the market environment and provide a solid foundation for the Chinese enterprises to expand the overseas market (Purnamasari E. 2017). In the tide of economic globalization, Chinese enterprises need to strengthen their English communication ability in order to better trade with other countries (LIU Zongcheng et al. 2017). This demand is not the academic needs of the past, but more precisely the need for technical types. Therefore, we need to improve the traditional English teaching mode and create a talent training model which is more in line with the requirements of the new era (Zhang Y X et al. 2017). In order to meet the demand of the market, make up the vacancy of the existing market and maximize the practical value of English teaching, this paper will focus on the analysis of English teaching behavior based on the association rules algorithm and explore its impact on the actual teaching effect to provide a theoretical basis for the future (Zhang M H et al. 2017).

\section{STATE OF THE ART}

After a period of discussion and research, the first international academic conference on data mining was formally convened in the 1990s (Jane C J et al. 2017). After years of development, the topics discussed are gradually changed from the theoretical discussion to the practical use, which promotes integration and progress among various disciplines. At the same time, it attaches great importance to the use of data mining technology and advocates the discovery of new data mining methods and the fusion of various mining methods (Kang $\mathrm{T}$ et al. 2017). In general, data mining technology has been developed for many years, and there have been several relative mature mining methods, such as association analysis, cluster analysis, etc. Because of the economic development, market demand for data mining will also becoming higher. It will guide the research and development force into market competition, and its 
practical application ability will also increase.

\section{METHODOLOGY}

As early as the early 1990s, researchers Agrawal and others discussed the association rules, and developed the corresponding data mining algorithm AIS, but at that time, it could not deal with more complex problems. In the second year, they put forward the theory of the lattice space of the project, and on this basis, the Apriori algorithm is derived. After that, many people began to enter the research of data mining in the association rules. Association rule is one of the most famous hot research fields in data mining. This algorithm remains a hot topic in this field until now, more and more people are paying attention to this field.

According to different requirements, the association rules can be divided into the following categories: the categories of variables based on rules and the association rules can be divided into Boolean and numerical ones. An important feature of Boolean association rules is that most of the values it analyzes are discrete and kind. The meaning of it is the relationship between variables and variables, but numerical association rules can combine multidimensional or multi-layer relations, so they usually process the fields dynamically, and can also operate directly on the original data. In this case, the numerical association rules can have types and variables. Secondly, based on the abstract level of the data in the rule, it can be divided into single layer association rules and multi-layer association rules. Generally, if a single layer association rule is determined; all variables will no longer be assumed to have other levels. But if we decide that the association rules are multilevel, we need to have a more comprehensive assumption of the data' s multilevel. Based on the dimension of the data involved in the rule, the association rules can be divided into single dimension and multidimensional. Usually, we only analyze the single dimension of data in single dimensional association rules, such as consumers who consume the goods.

\section{RESULT ANALYSIS AND DISCUSSION}

With the promotion of education information, higher requirements for English teaching behavior are put forward. Therefore, it is necessary to make a rational evaluation of the influence of teaching behavior and improve the quality of English teaching according to the content of the evaluation. At present, many domestic colleges and universities use information technology to improve the daily management level. The system and the database have been used in many colleges and universities, at the same time, the registry stores a lot of information about students. This information includes basic information, student achievement, employment situation and so on. But the processing of this information is mostly only in the query, sort, backup, and simple management phase. The rational use of these information can provide a lot of convenience to the evaluation work. In addition, it is necessary to use appropriate computer algorithms to improve the evaluation quality of English teaching behavior. Based on the above reasons, this paper designs and implements an English teaching behavior quality evaluation algorithm based on the fusion association rule algorithm. The algorithm directly divides the quality evaluation of English teaching behavior into four different evaluation subjects, namely student evaluation, peer and expert evaluation, leadership evaluation and teacher self-evaluation. The algorithm of the four kinds of evaluation subjects scoring statistics according to a certain weight, then according to the different evaluation subjects are effective interval of a comprehensive evaluation of the weights given the final effective score interval, and according to the effective interval the final evaluation grade. The algorithm implements the flow chart as shown in Figure 1:

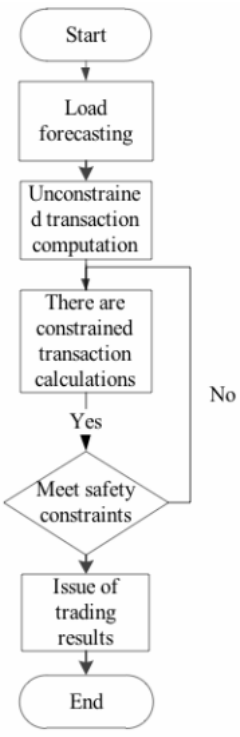

Fig. 1 The algorithm realizes flow chart 
According to the frequent item sets, the correlation rule generation algorithm is used to calculate the corresponding confidence degree. And then according to its confidence, the correlation strength between the students' knowledge points can be effectively calculated. To evaluate the knowledge of the students according to the intensity of their relevance, and then to evaluate the quality of teachers' English teaching behavior. In addition, through the analysis of achievements, teachers can find the weak points of students' study. By setting up links between knowledge points that need to be strengthened in personalized learning interface, remind students to review in time, consolidate relevant knowledge, help students improve their academic performance, and further improve their influence on English teaching behavior.

\section{CONCLUSION}

Due to the progress of algorithm and the more powerful computing power of computer, the computer algorithm is more and more mature, and its practicability is stronger and stronger. It can reduce people's workload in many ways, which makes the computer algorithm get a lot of application in real life. With the development of economic globalization and the continuous progress of Chinese enterprises, there is an increasing demand for English talents, which requires us to improve the traditional English teaching mode and create more qualified personnel training mode in line with the new era. Therefore, this paper focused on the analysis of English teaching behavior based on the association rules algorithm, and explored its effect on the actual teaching effect, which can provide a theoretical basis for English teaching behavior based on association rules algorithm in the future.

\section{[Reference]}

[1]Purnamasari E. WEB USAGE MINING FOR DISCOVERING USER BROWSING BEHAVIORS USING FT-GROWTH ALGORITHM AND ASSOCIATION RULE[J]. Computer Knowledge \& Technology, 2017, $11(8): 27$.

[2]LIU Zongcheng, ZHANG Zhonglin, TIAN Miaofeng. Analysis of Network Behaviors Based on Association Rules[J].Electronic Science and Technology, 2017, 28 (3) : 367-375.

[3] Zhang Y X, Bing-Jun Y U, Deng Z H. Application Research of Association Rule Algorithm Based on Bit Vector in Teaching Quality Evaluation[J]. Journal of Langfang Teachers University, 2017, 28(3):367-375.

[4]Zhang M H, Yun 0 U. Application of Data Mining in the Colleges' Teaching Quality Evaluation[J]. Computer Knowledge \& Technology, 2017,6 (7) :416-424.

[5] Jane C J. The Research of Grey Cloud Relational Analysis in Teaching Quality Evaluation[J]. Journal of Grey System, 2017, 18(3):488-492.

[6] Kang T, University N. The Application of Correspondence Analysis Method in the Quality Evaluation of Classroom Teaching $[\mathrm{J}]$. Mathematics in Practice \& Theory, 2017, 38(3):211-216.

\section{作者简介:}

肖菲,(1989.05-), 女, 汉族, 四川广汉人, 硕士, 讲师, 研究方 向：英语教学,英美文化。

\section{更正说明}

稿件《课题中心教学法理论下的韩语会话课教学模式构建》四川外国语大学成都学院, 作者周晗。该文章发表于 2019 年第 1 期。因编校原因, 其作者信息特做如下更正: 籍贯：四川宜宾 职称：助教 